\title{
The Impact of the Companies Act 71 of 2008 on the Traditional Director's Duty to Avoid Conflict of Interest
}

\author{
Jean Chrysostome Kanamugire \\ Lecturer, Faculty of Law, Mafikeng Campus, North-West University \\ Email: jean.kanamugire@nwu.ac.za
}

\section{Doi:10.5901/mjss.2014.v5n9p75}

\begin{abstract}
The director's duty to avoid conflict of interest has been recognised and developed by common law. This duty includes various rules. The self-dealing rule precludes a director from acting on behalf of the company in a transaction where he/she has an interest. The fair dealing rule requires the director to disclose his or her interest if he/she wants to perform a transaction with the company, or has an interest in a contract that the company plans to conclude with a third party. The director is not allowed to make secret profits at the expense of the company, nor to act in conflict with his/her duty. The director is prohibited from taking corporate opportunities that rightfully belong to the company. Occasionally, this duty may continue to exist beyond the period a person has ceased to be a director. Directors should refrain from competing with their companies. Directors must also keep information confidential in the performance of their duties. The Companies Act 71 of 2008 has codified the traditional director's common law duty to avoid conflict of interest, specifically the self-dealing and fair dealing rules. The Companies Act provides for director's personal financial interests, standards of directors' conduct, liability of directors and prescribed officers, and indemnification and directors' insurance. The codification of the duty to avoid conflict of interest will promote good corporate governance in South Africa.
\end{abstract}

Keywords: Avoid conflict of interest; self-dealing rule; fair dealing rule, corporate opportunity, secret profit, confidential information.

\section{Introduction}

A director may not place himself in a position in which he has, or can have, a personal interest or a duty to another, conflicting, or which possibly may conflict, with his duties to company. ${ }^{1}$ This duty is "based on the consideration that, human nature being what it is, there is a danger, in such circumstances, of the person holding a fiduciary position being swayed by interest rather than duty, and thus prejudicing those whom he is bound to protect."2 For this reason, the courts have created an "inflexible rule."3

In Aberdeen Rail Co. v Blaikie Brothers, ${ }^{4}$ Lord Granworth held that: "a corporate body can only act by agents, and it is, of course, the duty of those agents so to act as best to promote the interests of the corporation whose affairs they are conducting." 5 He continued to say that:

\begin{abstract}
Such an agent has duties to discharge of a fiduciary character towards his principal, and it is a rule of universal application that no one having such duties to discharge shall be allowed to enter into engagements in which he has or can have a personal interest conflicting or which possibly may conflict with the interest of those whom he is bound to protect. So strictly is this principle adhered to that no question is allowed to be raised as to the fairness or unfairness of a contract so entered into. 6
\end{abstract}

\footnotetext{
${ }^{1}$ Blackman, Jooste \& Everingham. Commentary on the Companies Act 2006 vol. 2 at p. 8-111; MS Blackman 'Companies' in WA Joubert LAWSA vol. 4 (2) Durban: Butterworths \& Co Ltd (1996) 209 para 128; Aberdeen Rail Co. v Blaikie Brothers 1843 - 60 All ER 249 (HL) 252-253; Cowan de Groot Properties Ltd v Eagle Trust PIc 19924 All ER 700 (ChD) 764-765; Tvl Cold Storage Co Ltd v Palmer 1904 TS 4 at 32-34; Robinson v Randfontein Estate Gold Mining Co Ltd 1921 AD 168 at 178 - 179; T Mongalo Corporate law and corporate governance. Claremont: New Africa Books, Ltd (2003) 167. T Mongalo, C Lumina \& F Kader. Forms of business enterprise theory, structure and operation. Claremont: New Africa Books (Pty) Ltd (2004) 225.

2 Bray v Dord 1895-99 All ER 1009 (HL) 1011 (by Lord Herschell). See also Breen v Williams (1996) 186 CLR 71 (HC of A) 108; Beach Petroleum NL v Abbot Tout Russel Kennedy [1999] 33 ACSR 1 (NSW) 45.

${ }^{3}$ Bray v Ford op cit (n. 2) 1011. See also J Lowry \& J Sloszar "Judicial pragmatism: directors' duties and post-resignation conflicts of duty" 2008 JBL 83, 84; R Edmunds \& J Lowry "The no conflict - no profit rules and the corporate fiduciary: challenging the orthodoxy of absolutism" 2000 JBL 122.

${ }^{4}$ Aberden Rail Co Ltd v Baikie Brothers op cit (n. 1).

5 Ibid 252.

${ }^{6}$ Ibid 252 I. See also R Cassim "Post-resignation duties of directors: the application of the fiduciary duty not to misappropriate corporate opportunities" (2008) 125 SALJ 731
} 
The question of fairness or unfairness of a contract does not arise because, according to Lord Granworth, it may be "impossible to demonstrate how far in any particular case the terms of such a contract have been the best for the cestui que trust which it was impossible to obtain." Hence the rule is so inflexible that "no inquiry on that subject is permitted." 8

From this general rule a number of particular duties are usually thought to follow: (a) the rule against self-dealing and the rule (the fair-dealing rule) that requires disclosure of interests in company contracts; (b) the duty to account for secret or incidental profits; (c) the duty not to take corporate opportunities; (d) the duty not to misuse confidential information; and (e) the duty not to compete with the company. ${ }^{9}$ These duties had been recognised and developed by the common law. Recently there has been a tendency to codify these duties, by including them in the Companies Act 71 of 2008 (Companies Act). This research will set out and analyse the above elements that constitute the director's traditional duty to avoid conflict of interest in their activities. In addition, the research will examine the current codification of this duty, such as the personal financial interests of a director, standards of directors' conduct, liability of directors and prescribed officers and indemnification and directors' insurance, as they appear in the Companies Act. Finally it will compare the traditional position and the Companies Act concerning the director's duty to avoid conflict of interest and provide conclusion.

\section{The Traditional Director's Duty to Avoid Conflict of Interest}

\subsection{Self-dealing rule}

The self-dealing rule prevents a director from acting "on behalf of his company in any matter in which he has an interest (or in regard to which he owes a duty to another) that conflicts or may possibly conflict, with his duty to his company." 10 In Robinson v Randfontein Estates Gold Mining Co Ltd, Innes CJ said that the fiduciary principle "prevents an agent from properly entering into any transaction that would cause his interest and his duty to clash. If employed to buy, he cannot sell his own property; if employed to sell, he cannot buy his own property."11 The reason for the rule is that as a director of the company he is under a duty to obtain the best possible terms for it, while his personal interest in the transaction would lead him to an entirely opposite direction. ${ }^{12}$ This is the very evil against which the rule in question is directed. ${ }^{13}$ The selfdealing rule ensures that a company obtains unbiased advices from its directors in their activities since they cannot perform any transaction whereby they have an interest or may possibly have an interest.

In certain circumstances, a director can perform an activity where he or she has an interest. "A director may, however, act on behalf of his company in a contract or other matter in which he has an interest if he obtains the consent of the general meeting to do so, after making full disclosure to it of his interest in the contract." ${ }^{4}$ The general rule is that disclosure must be made to the members in general meeting, and that they alone have the power to sanction the contract. ${ }^{15}$ In Boulting and Another v Association of Cinematograph Television and Allied Technicians, ${ }^{16}$ Upjohn LJ held that "the law is clearly laid down that a bargain, which if secret is corrupt, ceases to be so if disclosed to the person entitled to complain and assented to by him."17 If the company gives its informed consent to the transaction in the general meeting, there is no breach and the conflict of interest is avoided. Furthermore, the articles of a company may relax the rule by permitting a director to act in such matters, after making full disclosure of his interest to the other members of the board. ${ }^{18}$ The disclosure must be done to the independent board of directors, otherwise they cannot properly fulfil their

\footnotetext{
${ }^{7}$ Aberden Rail Co Ltd v Baikie Brothers op cit (n. 1) 252.

8 Ibid 253.

${ }^{9}$ MS Blackman op cit (n. 1) 209 para 128.

10 Ibid para 129; Blackman, Jooste and Everingham op cit (n. 1) 8 - 122; Aberdeen Railway Co Ltd v Blaikie Brothers op cit (n. 1) 252 - 253; Cohen v Directors of Rand Collieries Ltd 1906 TS 197 at 201-202; Robinson v Randfontein Estates Gold Mining Co Ltd op cit (n.1) 178.

${ }_{11}^{1}$ Robinson v Randfontein Estates Gold Mining Co Ltd op cit (n.1) 178. See also Anderson v Hargreaves 1914 CPC 1027 at 1032; Hargreaves v Anderson 1915 AD 519 at 525-526 and Osry v Hirsch, Luubser \& Co Ltd 1922 CPD 531.

12 Aberdeen Railway Co Ltd v Blaikie Brothers op cit (n. 1) 253.

${ }^{13} \mathrm{lbid}$.

${ }^{14}$ African Claim and Land Co Ltd v WJ Langerman 1905 TS 494 at 523, Furs Itd v Tomkies (1935) 54 CLR 583 (HC of A); Boulting v Association of Cinematograph, Television and Allied Technicians [1963] 1 All ER 716 (CH) 729; Nepture (Vehicle Washing Equipment) Ltd v Fitzgerald [1995] 3 All ER 811(ChD) at 814; Blackman, Jooste and Everingham op cit (n. 1) 8-123.

15 Imperial Mercantile Credit Association v Coleman (1871) 6 Ch App 55 at 567-568; Africa Claim and Land Co Ltd v WJ Langerman 1905 TS 494 at 523; Gray v New Augarita Porcupine Mines Ltd (1952) 3 DLR 1 (PC) 13; Guiness Plc v Saunders 19901 All ER 652 (HL) 661 - 662; Woolworths Ltd v Kelly (1991) 4 ACSR 431 CA (NSW) 438.

${ }^{16}$ Boulting and Another v Association of Cinematograph Television and Allied Technicians [1963] 1 All ER 716 (CA).

17 Ibid 729 .

${ }^{18}$ Novick v Comair Holdings Ltd 19792 SA 116 (W) 152-153.
} 
duties if they are not independent. The director concerned must not be part of the board that takes a decision. The next issue deals with circumstances in which a director operates with another person with whom he or she has some personal relationship.

\subsection{Disclosure of information in contracts (fair-dealing rule)}

A director may validly contract with his company. ${ }^{19}$ If a director wishes to contract with his company, or has an interest in a contract which his company proposes to enter into with a third party, he must, in-so-far as that contract is concerned, entirely shake off his relationship with the company, act openly and in good faith, and (where he is the other party to the contract) deal with the company at arm's length. ${ }^{20}$ In Rabinson v Randfontein Estates Gold Mining Co Ltd, Innes CJ held that conflict of interest "prevents an agent from properly entering into any transaction which would cause his interests and his duty to clash." 21 However, "there is only one way by which such transaction can be validated, and that is by the free consent of the principal following upon a full disclosure by the agent. In such a case, the special relationship quoad that transaction falls away and the parties deal at arm's length with one another."22 This is a fair-dealing rule. The operation of this rule has been defined in Tito $v$ Waddell (No 2), ${ }^{23}$ per Megarry V-C, where he said: "If a trustee purchases his beneficiary's beneficial interest, the beneficiary may have the sale set aside unless the trustee can establish the propriety of the transaction, showing that he had taken no advantage of his position and that the beneficiary was fully informed and received full value."24

In Woolworths Ltd v Kelly, ${ }^{25}$ Samuels JA said: "the requirement for the disclosure is not intended to protect the company against the bad bargains, but to ensure that honesty and integrity which should inform corporate dealing and, in particular, the internal management of the companies, is scrupulously observed." 26 Since the company has other directors, they are in a better position to protect the interests of the company when dealing with another director. When making a disclosure of interest, a person (a director) must state what his or her interest is. In the Rabinson case, the court held that "it was not enough that the board should know that the defendant had an interest; to constitute a disclosure it was necessary that they should have known the nature of the interest." 27 If a director does not disclose his or her interests in a transaction, severe consequences may follow.

\subsubsection{Consequences of failure to make disclosure}

If a director fails to make the required disclosure, the contract is voidable against him at the instance of the company. ${ }^{28}$ This means that the company has a discretion to either abide by the contract or set it aside. Where the contract is with a third party, the company can rescind it only if the third party knew, or in the circumstances ought to have known, that the director was acting in breach of his or her duty. ${ }^{29}$ In Tito $v$ Waddel (No 2), Meggary V-C said that, where "a trustee purchases the beneficial interest of any of his beneficiaries, the transaction is not voidable ex debito justitiae, but can be set aside by the beneficiary unless the trustee can show that he has taken no advantage of his position and has made full disclosure to the beneficiary, and that transaction is fair and honest." 30

\footnotetext{
${ }^{19}$ Hely - Hutchinson v Brayhead Ltd [1967] 2 All ER 14 (QBD) 27. In this case, Roskill J held that: 'There is no rule of common law that a director cannot validly contract with a company of which he is a director.' Equity ensured, however, that the company could, when appropriate, recover any profit made by the director as a result of his making such a contract with the company by reason of his fiduciary position, unless he was relieved from the obligation so to account by compliance with the relevant article or statutory provision. Further, in certain cases, equity would permit the company to avoid the contract. See also Anderson v Hargreaves 1914 CPD 1027 at 1032.

${ }^{20}$ MS Blackman op cit (n. 1) 212 para 130; N Bouwman "Avoiding a conflict of interest" 2011 Without Prejudice 28, 29; Magnus Diamond Mining Syndicate v Macdonald and Hawthorne 1909 ORC 65 at 79, Robins v Randfontein Estates Gold Mining Co Ltd op cit (n. 1) 178; Osry v Hirsch, Loubser \& Co Ltd 1922 CPD 531 at 548; Peffers, NO and Another v Attorney, Notaries and Conveyancers Fidelity Guarantee Fund Board of Control 19652 SA 53 (C) 56 ; S v Heller (2) 19641 SA 524 (W) 537.

${ }^{21}$ Robinson v Randfontein Estates Gold Mining Co Ltd op cit (n. 1) 178

22 Ibid 178.

${ }^{23}$ Tito and Others v Wadell and Others (No 2) [1977] 3 All ER 129 (ChD).

24 Ibid 228.

${ }^{25}$ Woolworths Ltd v Kelly (1991) 4 ACSR 431 CA (NSW).

${ }^{26}$ Ibid 442.

${ }^{27}$ Robinson v Randfontein Estates Gold Mining Co Ltd op cit (n. 1) 260.

${ }^{28}$ Cohen v Directors of Rand Collieries Ltd 1906 TS 197 at 201-202; Guiness PIc v Saunders 19901 All ER 652 (HL) 662, 664-665; Africa Claim \& Land Co Ltd v WJ Langerman 1905 TS 494 at 565-506. See also MM Botha "The role and duties of directors in the promotion of corporate governance: a South African perspective" 2009 Obiter 702, 708.

${ }^{29}$ MS Blackman op cit (n. 1) 218 para 130; EMB Co Ltd v Dominion Bank 19373 All ER 555 (PC) 569.

30 Tito $v$ Waddel (No 2) op cit (n. 23) 241.
} 
As a condition to a rescission there must be a restitutio in integrum..$^{31}$ If the contract is rescinded, the company must only refund to the director what he or she has paid under the contract. This is because the court "treats the acquisition as one made in the interest of the company." 32 Therefore, the company may claim any profits made by the director as a result of the contract and any loss that it had suffered as a consequence of the director's non-disclosure. The director is still "liable for damages if, having originally failed to disclose, he, then, by deliberate acts of his own, prevents the knowledge of the position reaching the company until restitution has become impossible." ${ }^{33}$ In $S$ v Heller, ${ }^{34}$ Trollip JA said that "the mere non-disclosure, even though actionable, does not necessarily constitute fraud in its precise and proper sense."35

\subsection{Duty to account for incidental or secret profits}

Where one man stands to another in a position of confidence involving a duty to protect the interests of that other, he is not allowed to make a secret profit at the other's expense or place himself in a position where his interests conflict with his duty. ${ }^{36}$ A director must account to his company for all profits acquired by him, unless acquired or retained with the full knowledge and consent of other directors. ${ }^{37}$ This principle prevents the director from using his or her position in the company to enrich himself or herself. If a secret profit is made by directors in the course or scope of the execution of their office as directors, they are liable to account to the company. ${ }^{38}$

In Regal (Hastings) Ltd v Gulliver and Others, ${ }^{39}$ the appellant company was the owner of a cinema in Hastings and they wanted to acquire other two cinemas. For this purpose, they formed a subsidiary company with a capital share of $£ 1$ shares. As the company could only pay for 2000 shares, the directors and their friends managed to subscribe for the remaining 3000 shares. Subsequently, the subsidiary company was sold and the directors obtained benefit from the shares. The new shareholders of the company successfully instituted an action, on behalf of the appellant company, to recover from the directors the improper benefits they had obtained while they were directors.

This case confirms the general principle that "any person in a fiduciary capacity is not allowed to make a profit out of property in regard to which a fiduciary relationship exists." 40 Since the friends of directors were not in a fiduciary duty to the subsidiary company, they were allowed to keep their profits. During the course of judgment, their Lordships pointed out that "no question as to the right to retain this profit could have arisen if the respondents had taken the precaution of obtaining the approval of the appellant company in general meeting, and this would have been a mere matter of form, since they doubtless controlled the voting." 41

However, in Cook v Deeks and Others, ${ }^{42}$ the respondents acquired a railway transaction for themselves by virtue of their position as directors. As they held majority voting rights, they passed a resolution in the general meeting of shareholders to the effect that the company had no interests in the transaction. The court refused to ratify their decision. Lord Buckmaster LC stated that "a resolution that the rights of the company should be disregarded in the matter would amount to forfeiting the interest and property of the minority of shareholders in favour of the majority." 43 They had committed a fraud on a minority and the court refused to sanction the resolution.

The rule against secret or incidental profits is an inflexible one and its object is "to prevent directors from placing themselves in a position where they may be tempted to prefer their own interests to those of their company." 44 In certain cases, where a fiduciary has acted with complete honesty and in the interest of his beneficiary, the courts have tempered the rigour of the no profits rule by allowing him to retain as a quantum meruit a sum in respect of his own work and skill.45 In Boardman and Another v Phillips, Lord Hadson granted the payment "on a liberal scale in respect of the work and skill

\footnotetext{
${ }^{31}$ MS Blackman op cit (n. 1) 218 para 133; Erlanger v new Sombrero Phosphate Co [1874-88] All ER 271 at 286.

${ }^{32}$ Robinson v Randfontein Estates Gold Mining Co Ltd op cit (n. 1) 180.

${ }^{33}$ Blackman, Jooste and Everingham op cit (n. 1) 8-137 - 8-138; Cavendish - Bentinch v Fenn (1887) AC 652 (HL) 666.

${ }^{34} \mathrm{~S} v$ Heller and Another 19641 SA 524 (W).

${ }^{35}$ Ibid 536-537.

${ }^{36}$ Robinson v Randfontein Estates Gold Mining Co Itd op cit (n. 1) 177; Botha (note 28 above) 707.

${ }^{37}$ MS Blackman op cit (n. 1) 220 para 134. See also Blackman, Jooste and Everingham op cit (n. 1) 8-142 (the no-profit rule).

${ }^{38}$ See Robinson v Randfontein Estates Gold Mining Co Ltd op cit (n. 1) $179-180$.

${ }^{39}$ Regal (Hastings) Ltd v Gulliver and Others [1942] 1 All ER 378 (HL).

40 Ibid 379.

${ }^{41}$ Ibid 379. See also Bamford v Bamford [1969] 1 All ER 696 (CA) 972.

42 Cook v Deeks and Others 1916 AC 554.

43 Ibid 564.

${ }^{44}$ MS Blackman op cit (n. 1) 220 para 134; Boardman and Another v Phipps [1966] 3 All ER 721 (HL) 756-757; Guiness PIc v Saunders 19901 All ER 652 (HL) 659-660.

${ }_{45}$ MS Blackman op cit (n. 1) 221 para 134; Phipps v Boardman and Others 19642 All ER 187 (ChD) 208.
} 
employed in obtaining the shares and the profits therefrom." 46 This is simply compensation to the director for the work done for the company, rather than an award of profit. The company needs to compensate directors for their works and skills used for its benefit, otherwise it may be held liable for unjust enrichment. However, the rule against secret or incidental profits is strictly applied to discourage directors from participating in activities where their interests conflict with those of the company. ${ }^{47}$ Furthermore, they are not allowed to take corporate opportunities.

\subsection{Duty not to take corporate opportunities}

A corporate opportunity "connotes any economic or business opportunity, whether property or rights, which rightfully belongs to the company or to which the company has some kind of claim." ${ }^{48}$ As a general principle, "a man who stands in a position of trust towards another, cannot, in matters affected by that position, advance his own interests (e.g. by making a profit) at that other's expense." ${ }^{99}$ For instance, a director cannot acquire a property that constitutes a corporate opportunity and re-sell it to the company at a profit. This means that the law does not give effect to his or her intention; "it treats the acquisition as one made in the interests of the company." " 50 "Clearly a director acts in breach of his fiduciary duty to the company where he sabotages the company's contractual opportunities for his own advantage, or where he uses confidential information to advance the interest of a rival concern or his own business to the prejudice of those of his company. ${ }^{.1}$ Indeed, a director has a duty not to misappropriate corporate opportunities. ${ }^{52}$

Sometimes a company may be unable to pursue an opportunity in its activities. This depends on various reasons such as "restrictions in the company's constitution or separate contracts, other legal constraints, inability to finance the venture, absence of adequate physical facilities to make use of the opportunity, and unwillingness of the party offering the opportunity to deal with the company." ${ }^{53}$ It must undeniably be a corporate opportunity. "In order to constitute a corporate opportunity, the opportunity should not only be in the line of business of the company, but the company should also be seen to have justifiably been relying on the fiduciary to acquire it or to assist in its acquisition for the company." ${ }^{44}$

Financial inability may be a reason for a company's failure to acquire a corporate opportunity. "Most commonwealth decisions refuse corporate inability, or rejection of the particular opportunity by the company as a defence" 55 for the director to acquire a corporate opportunity. In the United States of America, courts seem to accept that the "financial inability of a corporation to take up a corporate opportunity absolves directors from liability for making personal use of opportunity, subject to certain restrictions which are quiet broad in scope."56 The matter is still unsettled in South Africa. It is submitted that directors should be allowed to acquire the corporate opportunity if the company is financially unable to do so or has genuinely rejected it.

A director cannot divest himself of his duty by resigning from the company. ${ }^{57}$ In Magnus Diamond Mining Syndicate $v$ Macdonald and Hawthorne, ${ }^{58}$ Maasdorp, $\mathrm{CJ}$ held that the fact that the defendants resigned their directorships did not affect their position in any way. "That resignation was merely an attempt to divest themselves of the responsibilities and obligations of their office, from which they could not in law free themselves without the consent of the corporation." 59 Where a director's resignation is influenced by a wish to acquire for himself an opportunity, or where his position with the company, rather than a fresh initiative, led him to the opportunity, he remains precluded from taking it. ${ }^{60}$ In Industrial

\footnotetext{
${ }^{46}$ Boardman and Another v Phipps [1966] 3 All ER 721 (HL) 749.

47 Ibid 756, 757.

${ }^{48}$ M Havenga. Corporate opportunities: A South African update (part 1) (1996) 8 SA Merc LJ 40 at 43; M Havenga. Directors in competition with their companies (2004) 16 SA Merc LJ 275 at 285; RC Beuthin. Corporate opportunities and the non-profit rule (1978) 95 SALJ 458 at $462 ;$ DD Prentice "The corporate opportunity doctrine" 1974 MLR 464; Blackman, Jooste and Everingham op cit (n. 1) 8-161; M Havenga "Directors' exploitation of corporate opportunities and the Companies Act 71 of 2008" 2013 TSAR 257.

${ }^{49}$ Robinson v Randfontein Estates Gold Mining Co Ltd op cit (n. 1) 179.

50 Ibid 180.

${ }^{51}$ Cybercene Ltd and Others v I- Kiosk Internet and Information (Pty) Ltd 20003 SA 806 (C) 821 A-B; see also T Achada. Don't take what isn't yours (2002) $10 \mathrm{JBL} 176$ at 177.

${ }^{52}$ Rabinson v Randfontein Estates Gold Mining Co Ltd op cit (n. 1) 200.

${ }^{53}$ M Havenga. Appropriation of corporate opportunities by directors and employees 2007 TSAR 169 at 175-176.

54 Ibid 176.

55 Ibid 176. Furs Ltd v Tomkies (1936) 54 CLR 583 (HC of A) 592; Worman International Ltd v Dowyer (1994-1995) CLR 544 (HC of A) 558; Natural Extracts (Pty) Ltd v Stotter (1997) 24 ACSR 110 (Fed. Court Australia) 138. Consul Development Pty Ltd v DPC Estates Pty Ltd 1974132 CLR 373 (HC of A) 395; Hurley v BGH Nominee (Pty) Ltd (1984) 10 ACLR 197 SC (NSW) 200.

${ }^{56}$ M Havenga op cit (n. 53) 176. The old case of Irving Trust Co v Deutch 73 F $2 d 121$ (2nd Cir 1934) did not allow a financial inability as a defence for directors to take up the corporate opportunity.

${ }^{57}$ MS Blackman op cit (n.1) 225 para 135; Canadian Aero Services Ltd v O' Mallley (1974) 40 DLR 3d 371 (SCC) 382.

${ }_{58}$ Magnus Diamond Mining Syndicate v Macdonald and Hawthorne 1909 ORC 65 at 81.

${ }^{59}$ Ibid 81.

${ }^{60}$ MS Blackman op cit (n. 1) 225 para 135; Canadian Aero Service Ltd v O’ Malley (1974) 40 DLR 3d 371 (SCC) 382.
} 
Development Consultants Ltd $v$ Cooley, ${ }^{61}$ the defendant was a managing director and resigned from his office in order to benefit from the opportunity he had received due to his position. In fact, he misrepresented his state of health and was released from his directorship. He used the opportunity received and acquired employment. The court held that he had to account for the plaintiff company. ${ }^{62}$ This demonstrates that fiduciary duty may continue even after resignation.

In Phillips v Fieldstone Africa (Pty) Ltd and Another, ${ }^{63}$ the court extended the fiduciary duty to an employee and held him to account for the profit he had made out of shares he had bought during his employment. 64 "Employees stand in a fiduciary position to the company and the scope of that duty depends on the circumstances and position of the particular employee." ${ }^{65}$ As a result, they should not appropriate corporate opportunities for their personal gain. The fiduciary duty of the employee should depend on the nature of what he or she is employed to do, his or her position and the activities of the company. If the opportunity is unrelated to the activities of the company, the employee should be allowed to take it.

\subsection{Duty not to compete with the company}

In London and Mashonaland Exploitation Co v New Mashonaland Exploitation Co, 66 the court held that if it is "not appearing from the regulations from the company that a director's services must be rendered to that company and to no other company, he was at liberty to become a director even of a rival company, and it not being established that he was making to the second company any disclosure of information obtained confidentially by him as a director of the company he could not at the instance of that company be restrained in his rival directorate." 67 Each individual director is not as such an agent of the company and is, therefore, as a rule, free to transact business in his own account, even in competition with the company of which he is a director. ${ }^{68}$ This rule may not be entirely correct since a director who becomes simultaneously a director for a rival company creates a situation which conflicts, or may possibly conflict, with his or her position.

In Atlas Organic Fertilizers (Pty) Ltd v Pikkewyn Ghwano (Pty) Ltd and Others, ${ }^{69}$ van Dijkhorst J held that "it is inconceivable that this freedom to hold directorships in competing companies can exist in the case of a managing director actively so employed. It is impossible for one to advance the conflicting interests of two actively competing businesses as managing director of both." ${ }^{70}$ In the same case, a managing director was held guilty of a breach of his fiduciary duty where he sabotaged his company's chances to obtain a contract and later, after severing connection with his company, subverted and took over the contract for his new company. ${ }^{71}$ This is one of the conflicts that may arise when a director serves two or more rival companies at the same time.

In Cook v Deeks, Lord Buchmaster held that “... men who assume the complete control of a company's business must remember that they are not at liberty to sacrifice the interests which they are bound to protect, and, while ostensibly acting for the company, divert in their own favour business which should properly belong to the company they represent."72 According to the position of trust occupied by a director, van Dijkhorst J said: "it is a duty to act for the benefit of the company and not for his own benefit." 73 It follows that a director should not engage in activities that compete with his or her company.

In the absence of special circumstances such as a prohibition in the service contract, no breach is committed merely because the director takes steps so that, on the termination of his or her office, he or she can immediately set up

\footnotetext{
61 Industrial Development Consultants Ltd v Cooley 19722 All ER 162 (Assizes).

62 Ibid 176. See also Cassim (note 6 above) 742.

${ }^{63}$ Phillips v Fieldstone African (Pty) Ltd and Another 20043 SA 465 (SCA).

64 Ibid 480 - 482 Heher JA's judgment especially at 482D.

${ }^{65} \mathrm{M}$ Havenga op cit (n. 50) 176.

${ }^{66}$ London and Mashonaland Exploitation Co v New Mashonaland Exploitation Co 1891 WN 165 (ChD). See also M Havenga." Competing with the company - when does a director breach his or her fiduciary obligations?" (1995) 7 SA Merc LJ 435 at 437; M Christie "The director's fiduciary duty not to compete" (1992) 55 MLR 506 at 509; LCB Gower et al. Gower's principles of modern company law $4^{\text {th }}$ ed. London: Stevens \& Sons (1979) 599; B Pettet. Company law. Essex: Pearson Educating Limited (2001) 186; G Morse \& S Girvin. Charlesworths's company law $7^{\text {th }}$ ed. London: Sweet and Maxwell (2005) 310.

${ }^{67}$ Ibid as quoted by Lord Blanesburgh in Bell and Another v Lever Brothers Ltd and Others 1932 AC 161 (HL) 165.

${ }^{68}$ Robinson v Randfontein Estates Gold Mining Co Ltd op cit (n. 1) 216.

${ }^{69}$ Atlas Organic Fertilizers (Pty) Ltd v Pikkewyn Ghwano (Pty) Ltd and Others 19812 SA 173 (T).

70 Ibid 198.

${ }^{71} \mathrm{Ibid}$ 197. See also R Grantham. "Can directors compete with the company?" (2003) 16 MLR 109 at 110 - 111; Edmunds \& Lowry (note 2 above) 125.

${ }^{72}$ Cook v Deeks op cit (n. 42) 563.

${ }^{73}$ Atlas Organic Fertilizers (Pty) Ltd v Pikkenwyn Ghwano (Pty) Ltd and others op cit (n. 66) 197; Robinson v Randfontein Estates Gold Mining Ltd op cit (n.

1) 177 - 180; R v Herholdt and Others 19573 SA 236 (A) at 258D; S v De Jager and Another 19652 SA 616 (A) at $625 B$.
} 
business in competition with the company. ${ }^{74}$ The director is not thereafter precluded from using her general fund of skill and knowledge, or his/her personal connections, to compete, but may not, after resignation, pursue a maturing business opportunity of the company, ${ }^{75}$ or use confidential information of the company. ${ }^{76}$

In Atlas Organic Fertilizers (Pty) Ltd v Pikkewyn Ghwano (Pty) Ltd and Others, the court held that "the mere incorporation of a competing company on the initiative of a managing director, whilst serving his month's notice, was not a breach of his fiduciary obligation."77 In business, lawful competition is allowed. The law condones inducing an employee to terminate his or her employment lawfully. However, "it is unlawful competition to induce employees to terminate their employment not to benefit from their services but to cripple the competitor." ${ }^{\prime 78} \mathrm{~A}$ director should not compete with his or her company, even during a notice period.

In Movie Camera Company (Pty) Ltd $v$ Van Wyk, ${ }^{79}$ the court dealt with a managing director who took employment in competition with his former company after his resignation. The court considered that the director's resignation had been brought about by unhappiness working for the plaintiff and had in no way been part of any deliberate strategy or intention to set himself up in competition with the plaintiff. ${ }^{80}$ His contract with the competitor, whom he joined after his resignation, had been established in his personal capacity and did not relate to his position with the plaintiff. ${ }^{81}$ After his resignation he had been offered other positions and he had continued to work diligently and faithfully for the plaintiff during his notice period. ${ }^{82}$

Taking steps to set up a competing business during the notice period is acceptable, but the director still has to be wary of actual competition, or of appropriating opportunities that rightfully belong to the company. ${ }^{83} \mathrm{He}$ or she may not use confidential information or trade secrets of the company. ${ }^{84} \mathrm{As}$ long as a director does not use confidential information or trade secrets of the company, he or she can perform competitive activities with the company after his or her resignation. It is submitted that a person who is a director should not compete with his or her company, even if he or she does not use confidential information or trade secrets that belong to the company. This is because a director may be tempted to use confidential information or trade secrets of the company to his or her own benefit if he or she is allowed to do so.

\subsection{Duty not to misuse confidential information}

"A director or officer is under a fiduciary duty not to use for his own purposes, or to disclose, confidential information entrusted to him concerning his company's affairs, and he may be restrained from doing so even after the termination of his office." ${ }^{85}$ In Sibex Construction (SA) (Pty) Ltd and Another v Injectaseal CC and Others, ${ }^{86}$ the court held that, as an established law, "it was unlawful for an employee to use his employer's confidential information in order to compete with the employer." 87 For a material to be confidential it must not be something which is public property or public knowledge. ${ }^{88}$ The company may be entitled to rely upon two distinct causes of action, viz (1) unfair competition; and (ii) breach of fiduciary duty. ${ }^{89} \mathrm{In}$ this case, a managing director and a general manager resigned and established a company that provided similar services to the previous company. They used confidential information acquired during their previous services in the company and solicited more customers from the former company. The court held that "the use of such

\footnotetext{
${ }^{74}$ CMS Havenga. "Directors in competition with their companies "(2004) 16 SA Merc LJ 275 at 282; See also Flamlington Group PIC and Another V Anderson and others [1995] 1 BCLR 474 (ChD) at 498 A-B.

${ }^{75}$ CMS Dolphin Ltd v Simonet \& Another [2001] 2 BCLC 704 (ChD) at 733 e-d; Lowry \& Sloszar (note 2 above) 88.

${ }^{76}$ Dranez Ansalt \& Others v Hayet \& Others [2002] 2 BCLC 692 (ChD).

${ }_{77}$ Atlas Organic Fertilizers (Pty) Ltd v Pikkewyn Ghwano (Pty) Ltd op cit (n. 69) 198 - 199.

78 Ibid 173

${ }^{79}$ Movie Camera Company (Pty) Ltd v Van Wyk [2003] 2 All SA 291 (C).

${ }^{80}$ Ibid 311 para 54

${ }^{81} \mathrm{lbid}$.

82 Ibid.

${ }^{83}$ M Havenga op cit (n. 74) 283; MF Cassim "Da Silva v C H Chemicals (Pty) Ltd: fiduciary duties of resigning directors" 2009 SALJ 61.

${ }^{84}$ Sibex Constructions SA (Pty) Ltd v Injectaseal CC \& Others 19882 SA 54 (T).

${ }^{85}$ MS Blackman op cit (n. 1) 230 para 137; Bell v Lever Brothers Ltd 1931 All ER 1 (HL) 17; Bennetts v Board of Fire Commissioners of NSW (1967) 87 WN (pt 1) (NSW) 307; Sibex Constructions SA (Pty) Ltd Injectaseal CC \& Others 19882 SA 54 (T); Industrial Development Ltd v Cooley 19722 All ER 162 (Assizes); M Havenga. Corporate opportunities: A South African update (Part 2) (1996) 8 SA Merc LJ 233 at 234, 243; HS Cilliers and ML Benade. Company law $4^{\text {th }}$ ed. Durban: Butterworths (1982) 329 at 22.19.

${ }^{86}$ Sibex Construction Development SA (Pty) Ltd v Injectaseal CC and Others op cit (n. 81).

${ }^{87}$ Ibid 55, 64. See also Easyfind International (SA) (Pty) Ltd v Instataplan Holdings and Another 1983 3 SA 917 (W) 927D-E; Harvey Tiling Co (Pty) Ltd v Rodomac (Pty) Ltd and Another 19771 SA 316 (T) 321.

${ }^{88}$ Sibex Construction Development SA (Pty) Ltd v Injectaseal CC and Others op cit (n. 84) 64.

${ }^{89}$ Sibex Construction Development SA (Pty) Ltd v Injectaseal CC and Others op cit (n. 84) 63 C-D.
} 
information had constituted unfair and unlawful competition." 90 The court granted an interdict to use confidential information for one year. In Atlas Organic Fertilizers (Pty) Ltd v Pikkewyn Ghwano (Pty) Ltd and Others, the court found that the managing director "had breached his fiduciary duties by canvassing certain employees of the company he was leaving for the new company during the period of notice." 1

The director's fiduciary duty reinforces and extends to the company's rights in regard to the confidential proceedings of its board. He or she must respect the confidential nature of the board affairs where the interests of the board itself so require. ${ }^{92}$ The obligation of directors is to keep secret any matter which is discussed, the communication of which might detrimentally affect the company; and even the issuing of information concerning who voted in what way on a particular resolution may detrimentally affect the working of a company if it is disclosed. ${ }^{93}$ If confidential information is misused, the company may sue the wrongdoer and rely on a breach of fiduciary duty, or an action in delict that can be based either on unlawful competition ${ }^{94}$ or infringement of the company's right to privacy. ${ }^{95}$ The director's duty to avoid conflicts of interest has been developed by common law, but recently the legislature has managed to codify them.

\section{Provisions of the Companies Act 71 of 2008 on the Director's Duty to Avoid Conflict of Interests}

The legislature has codified the common law traditional duty of directors to avoid conflict of interest in order to improve corporate governance. The Companies Act regulates the fiduciary duty to avoid conflict of interests in respect of director's personal financial interests, ${ }^{96}$ their standards of conduct, ${ }^{97}$ their liability, ${ }^{98}$ indemnification and insurance. ${ }^{99}$ The Act extends the definition of director to "include an alternate director, and a prescribed officer; or a person who is a member of a committee of a board of a company; or of the audit committee of a company, irrespective of whether or not the person is also a member of the company's board." 100 This definition includes prescribed officers who are not known, since the Minister has to make regulations designating any specific function or functions within a company to constitute a prescribed office. ${ }^{101}$

\subsection{Personal financial interests of a director (s. 75)}

The Companies Act provides that "If a person is the only director of a company, but does not hold all the beneficial interests of all the issued securities of the company, that person may not - approve or enter into any agreement in which the person or a related person has a personal financial interest; or as a director, determine any other matter in which the person or a related person has personal financial interest, unless the agreement or determination is approved by an ordinary resolution of the shareholders after the director has disclosed the nature and extent of that interest to the shareholders." ${ }^{102}$ This section codifies the self-dealing rule. This rule prohibits a director from dealing with himself or herself by participating in any activity of the company where he/she, or a related person, has a personal interest. ${ }^{103}$ The director will need to get an approval from the shareholders by an ordinary resolution to validate his or her transaction. The requirements of approval by the ordinary resolution of shareholders may be easy to fulfil, since the director can even be holding enough voting shares to allow him or her to pass such a resolution in this regard. In order to achieve the protection of the company, as well as shareholders, a special resolution or three-quarters of voting shareholders is necessary. The transaction should not operate to the detriment of the company or amount to a fraud on the minority.

At any time, a director may disclose any personal financial interest in advance, by delivering to the board, or shareholders, a notice in writing, setting out the nature and extent of that interest, to be used generally for the purposes of

\footnotetext{
90 Ibid 55.

${ }^{91}$ Atlas Organic Fertilizers (Pty) Ltd v Pikkewyn Ghwano (Pty) Ltd and Others op cit (n. 69) 174.

92 MS Blackman op cit (n. 1) 230 para 137.

${ }^{93}$ Harness v Commonwealth Bank of Australia Ltd (1993) 12 ACSR 165 SC (NSW) 174.

${ }_{94}$ Atlas Organic Fertilizers (Pty) Ltd v Pikkewyn Ghwano (Pty) Ltd op cit (n. 66) 199 - 201; Sibex Construction SA (Pty) Ltd op cit (n. 84) 63.

${ }_{95}$ Sage Holdings Ltd v Financial Mail (Pty) Ltd 19912 SA 117 (W) 132 - 134; Financial Mail (Pty) Ltd v Sage Holdings Ltd 19932 SA 451 (A) 464.

${ }^{96}$ Companies Act 71 of 2008 , s. 75 .

${ }^{97}$ Ibid s. 76.

98 Ibid s. 77.

99 Ibid s. 78.

$100 \mathrm{lbid}$ s. 75 (1), 76 (1), 77 (1) and 78 (1).

$101 \mathrm{Ibid}$ s. definitions (prescribed officer) read together with s. 66 (11); See also K Idensohn "The meaning of 'prescribed officers' under the Companies Act 71 of 2008" (2012) 129 SALJ 717

102 Companies Act (note 96 above) s. 75 (3) (a) and (b).

${ }^{103}$ See above page 2 (2.1. self-dealing rule).
} 
this section until changed or withdrawn by further written notice from that director. ${ }^{104}$ This subsection codifies the fairdealing rule. This rule prevents the director from dealing with his or her company in a transaction where he/she, or a related person, has a personal financial interest, unless there is a full disclosure of such interest. ${ }^{105}$ This allows both parties to be at arm's length during the transaction and improves fairness. The disclosure by a director assists the company (board of directors or shareholders) to make an informed decision on whether or not to approve the transaction of the director or related person.

If a director of a company has a personal financial interest in respect of a matter to be considered at a meeting of the board, or knows that a related person has a personal financial interest in the matter, the director - must disclose the interest and its general nature before the matter is considered at the meeting; must disclose to the meeting any material information relating to the matter and known to the director; may disclose any observations or pertinent insights relating to the matter if requested to do so by the other directors; if present at the meeting, must leave the meeting immediately after making any required disclosure; must not take part in the transaction of the matter, except making disclosure. ${ }^{106}$ These provisions also codify the fair dealing rule. They oblige the director to disclose his or her personal financial interest to the board before the matter is considered. He or she has a duty to divulge any personal financial interest of the related person. The director does not participate in the board meeting that considers the matter and this ensures an unbiased decision.

A director, while absent from the meeting that considers the matter where he/she or a related person has an interest - is to be regarded as being present at the meeting for the purpose of determining whether or not sufficient directors are present to constitute the meeting; and is not to be regarded as being present at the meeting for the purpose of determining whether a resolution has sufficient support to be adopted; and must not execute any document on behalf of the company in relation to the matter unless specifically requested or directed to do so by the board. ${ }^{107}$ This provision is partially flawed, since a director can be regarded as present in order to fulfil the quorum and be considered as absent for the purpose of making a decision. The director should not participate in his or her transaction for the purpose of meeting a quorum. If there are not sufficient directors present, the meeting ought to be postponed until the quorum is achieved.

If a director of a company acquires a personal financial interest in an agreement or other matter in which the company has a material interest, or knows that a related person has acquired a personal financial interest in the matter, after the agreement and other matter has been approved by the company, the director must promptly disclose to the board or the shareholders, the nature and extent of that interest, and the material circumstances relating to the director or related to the person's acquisition of that interest. ${ }^{108}$ If a director or a related person makes a transaction with the company, where he or she has a personal financial interest, without the required disclosure, the contract is voidable at the discretion of the company. ${ }^{109}$ However, if the director or a related person acquires personal financial interest in the agreement or matter already approved by the company, compulsory disclosure must be made. This provision promotes honesty and integrity in corporate governance.

A decision by the board, or a transaction or agreement approved by the board, or by a company, is valid in spite of any personal financial interest of a director or person related to the director, if it - was approved in the manner contemplated in this section; or has been ratified by any ordinary resolution of the shareholders. ${ }^{110}$ This subsection provides unlimited powers for the board or company to use a fair-dealing rule or approve a transaction in which the director, or a related person, has a personal financial interest. It is submitted that if they commit a fraud on a minority, the transaction may be set aside.

A court, on application by any interested person, may declare valid a transaction or agreement that had been approved by the board or shareholders, as the case may be, despite the failure of the director to satisfy the necessary requirements. ${ }^{111} \mathrm{~A}$ provision also must be available for an aggrieved party to set aside the decision of the board or shareholders if there are valid reasons to do so. Since the decision of the courts is fair and just in all circumstances, there is no reason why they should not be given the power to declare the decision of the company or shareholders invalid, when appropriate.

\footnotetext{
104 Companies Act (note 96 above) s. 75 (4).

105 See above (2.2. fair-dealing rule).

${ }^{106}$ Companies Act (note 96 above) s. 75 (5) (a) - (e).

$107 \mathrm{lbid}$ s. 75 (5) (f) (i), (ii) and (g).

$108 \mathrm{lbid}$ s. 75 (6).

${ }^{109}$ See above (2.2.1. consequences of failure to make disclosure).

$110 \mathrm{lbid}$ s. 75 (7).

111 Ibid s. 75 (8).
} 


\subsection{Standards of directors' conduct (s. 76)}

A director of a company must - not use his position of a director, or any information obtained while acting in the capacity of a director - to gain an advantage for the director, or for another person other than the company; or knowingly to cause harm to the company or a subsidiary of the company. ${ }^{112}$ This section codifies the duty not to misuse confidential information that rightfully belongs to the company obtained while a person occupies the position of director. It also codifies the duty not to compete with the company, as well as the duty not to take corporate opportunities. A director of the company must communicate to the board, at the earliest practicable opportunity, any information that comes to the director's attention, unless the director reasonably believes that the information is immaterial to the company; or generally available to the public, or known to the directors; or is bound not to disclose that information by a legal or ethical obligation of confidentiality. ${ }^{113}$ These provisions codify the duty not to misuse confidential information. The information must be shared with the board of directors, so that they are able to work and improve the company.

A director of company, when acting in that capacity, must exercise the powers and perform the functions of director in the best interests of the company. ${ }^{114}$ This obligation will be satisfied, in respect of any particular matter arising in the exercise of the powers or the performance of the functions of director, if - the director has taken reasonably diligent steps to become informed about the matter; either -the director had no material personal financial interest in the subject matter of the decision, and had no reasonable basis to know that any related person had a personal financial interest in the matter; or the director complied with the requirements of section 75 with respect to any interest. ${ }^{115}$ This section codifies the director's duty not to take corporate opportunities.

\subsection{Liability of directors and prescribed officers (s. 77)}

A director of a company may be held liable, in accordance with the principles of common law relating to breach of a fiduciary duty, for any loss, damages or costs sustained by the company as a consequence of any breach by the director of a duty contemplated in sections 75,76 (2) or 76 (3) (a) or (b). ${ }^{116}$ These sections deal with circumstances in which a director or a related person has a personal financial interest in the transaction with the company. The liability of a person in terms of this section is joint and several with any other person who is, or may be, held liable for the same act. ${ }^{117}$ The provision of joint and several liability is significant to recover all benefits received by a director or a related person, if he or she has a personal financial interest in the transaction of the company. This encourages the directors and related persons to respect the duty to avoid conflicts of interest.

In addition to the liability set out elsewhere, any person who would be so liable is jointly and severally liable with all other such persons - to pay the costs of all parties in the court in a proceeding contemplated in this section unless the proceedings are abandoned, or exculpate that person; and to restore to the company any amount improperly paid by the company as a consequence of the impugned act, and not recoverable in terms of the Act. ${ }^{118}$ This, again, is the joint and several liability of the director and other persons involved where they have a personal financial interest in the transactions of the company. Proceedings to recover any loss, damages or costs for which a person is or may be held liable in terms of this section may not be commenced more than three years after the act or omission that gave rise to that liability. ${ }^{119}$ This is a prescription period of three years for a company to exercise its right to recover loss, damages or costs suffered as a result of a breach of a duty to avoid conflict of interest.

In any proceedings against a director, other than for wilful misconduct or wilful breach of trust, the court may relieve the director, either wholly or partly, from any liability, on any terms the court considers just if it appears to the court that - the director is or may be liable, but has acted honestly and reasonably; having regard to all circumstances of the case, including those connected with the appointment of the director, it would be fair to excuse the director. ${ }^{120}$ This rule is flexible and assists a director to maintain a transaction with the company where he or she has a personal financial interest. In addition the rule promotes honesty and reasonableness of the director and fairness in all circumstances. However the rule does not cover wilful misconduct or wilful breach of trust of a director when he or she deals with the

\footnotetext{
112 lbid s. 76 (2) (a) (i) and (ii).

113 Ibid s. 76 (2) (b) (i) and (ii).

114 lbid s. 76 (3) (b).

115 Ibid s. 76 (4) (a) (i) and (ii).

116 Ibid s. 77 (2) (a).

117 Ibid s. 77 (6).

118 Ibid s. 77 (8) (a) and (b).

$119 \mathrm{lbid}$ s. 77 (7).

120 Ibid s. 77 (9) (a) and (b).
} 
company.

A director who has reason to apprehend that a claim may be made alleging that the director is liable, other than for wilful misconduct or breach of trust, may apply to a court for relief, and the court may grant appropriate relief to the director. ${ }^{121}$ This section may be used by a director to validate his or her transaction, where he or she has a personal financial interest. It gives relief to a director, since he or she does not have to wait until a person brings an application to court to invalidate his or her action. However, the provision does not cover wilful misconduct or breach of trust of a director in his or her activities.

\subsection{Indemnification and directors' insurance (s. 78)}

Any provision of an agreement, the Memorandum of Incorporation or rules of a company, or resolution adopted by a company, whether express or implied, is void to the extent that it directly or indirectly purports to - relieve a director of a duty contemplated in section 75 or 76 ; or liability contemplated in section 77 ; or negate, limit or restrict any legal consequences arising from any act or omission that constitutes wilful misconduct or wilful breach of trust on the part of the director. ${ }^{122} \mathrm{~A}$ company may not indemnify a director in respect of any liability arising from wilful misconduct or wilful breach of trust on the part of the director. ${ }^{123}$ From these provisions, a director cannot be relieved of his or her responsibility in a transaction in which he or she has a personal financial interest, with respect to the duty to avoid conflict of interest. Furthermore he or she cannot be indemnified for wilful misconduct or breach of trust.

\section{Comparison between the Companies Act 2008 and the Traditional Duty to avoid Conflict of interest}

The Companies Act codifies and modifies, in certain circumstances, the common law director's duty to avoid conflict of interest. The self-dealing rule is codified in the Companies Act. ${ }^{124}$ In order to validate the transaction, a director must get approval by an ordinary resolution of the shareholders, after he or she has disclosed the nature and extent of his or her interest to the shareholders. ${ }^{125}$ This provision does not apply to one's man company. ${ }^{126}$

The Companies Act also codifies the fair-dealing rule and imposes a duty on a director not to use his or her position or information obtained as a director to benefit himself or herself, or another person. ${ }^{127}$ The duty not to compete with the company is codified by imposing an obligation on the director not "to knowingly cause harm to the company or a subsidiary of the company." ${ }^{128}$ Moreover, the Companies Act codifies the director's duty not to misuse confidential information, take corporate opportunity, compete with the company and his or her duty to account for secret or incidental profits. ${ }^{129}$

Some important improvements have been brought by the Companies Act. If a director of a company fails to observe the duty to avoid conflict of interest, he or she may be held liable in accordance with the principles of common law relating to breach of fiduciary duty for any loss, damages or costs sustained by the company as a consequence. ${ }^{130}$ In addition, the liability of a director is joint and several with any other person who is, or may be, held liable for the same act. ${ }^{131}$ This joint and several liability also includes payment of the costs of all parties in the court proceedings, unless they are abandoned and the restoration to the company of any amount improperly paid by it as a consequence of the impugned act. ${ }^{132}$

The Companies Act provides a possibility for a court, in any proceeding against the director, to relieve the director, either wholly or partly, from any liability, on any terms the court considers just if it appears to the court that the director is or may be liable, but has acted honestly and reasonably; or having regard to all the circumstances of the case, it would be fair to excuse the director. ${ }^{133}$ This provision does not deal with wilful misconduct or wilful breach of duty. ${ }^{134}$ This

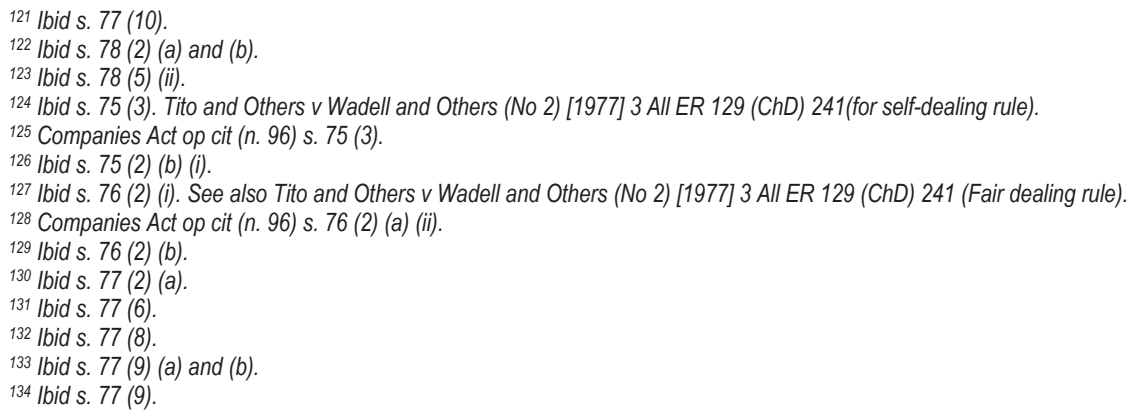


section appears to overrule the case of Regal (Hastings) v Gulliver [1942] 1 All ER 378 (HL), since the directors acted honestly, fairly and reasonably. They did not commit any wilful misconduct or wilful breach of duty in their activities. Moreover, a director may apply to a court for relief if he or she has reason to believe that a claim may be made alleging that he or she is liable. ${ }^{135}$ This provision protects directors in the performance of their activities if they have acted honestly and reasonably. It contributes to good corporate governance.

The prescription period for any activity of a director in breach of his or her duty to avoid conflict of interest is three years. ${ }^{136}$ After this period, no proceedings may be entertained to recover any loss, damages or costs for which the director may be liable. This will stimulate companies to act immediately and introduce proceedings in order to recover what the director has unlawfully taken, in breach of his or her duty.

\section{Conclusion}

The director's duty to avoid conflict of interest has been recognised and developed by common law. It includes the selfdealing rule, the fair-dealing rule, the duty to account for secret or incidental profits, the duty not to take corporate opportunity, the duty not to compete with the company and the duty not to misuse confidential information. The selfdealing rule prevents a director from acting on behalf of the company in a transaction in which he or she has an interest. If a director breaches the self-dealing rule, the transaction is voidable at the discretion of the company. This rule is inflexible, so that the transaction is voidable even if it is fair or benefits the company.

The fair-dealing rule requires the director to disclose his or her interest if he/she wants to enter into a transaction with the company, or has an interest in a contract that the company plans to conclude with a third party. The disclosure allows the parties to deal at arm's length, as the director has shaken off his or her relationship with the company. However, if the director fails to disclose his or her interest in the transaction, the contract is voidable at the discretion of the company. When the contract is with the third party, the company can only rescind it if the third party knew, or in the circumstances ought to have known, that the director was acting in breach of his or her duty.

A director occupies a position of utmost good faith with the company and he or she is not allowed to make a secret profit at the expense of the company, nor to act in conflict with his or her duty. He or she must use his or her position only to benefit the company. If the director obtains any benefit due to his or her position, he or she must account for the company. Directors are prohibited from taking corporate opportunities that rightfully belong to the company. This duty exists while they still occupy the position of directorship and terminates when they cease to occupy their positions. Sometimes the duty may continue to exist even beyond the period a person has ceased to be a director. This happens when a director has been induced to resign in order to take up a corporate opportunity received by virtue of his or her position. ${ }^{137}$ The directors are also precluded from taking up corporate opportunities that they have intercepted as a result of their occupation.

Directors should refrain from competing with their companies. As a director must render his or her service to the best of his or her ability, he or she cannot simultaneously occupy the position of directorship for two rival companies. If a person becomes a director for two or more rival companies, his or her duty in one company conflicts with his or her obligation to the other. The mere taking of steps to establish a rival company during the month's notice period is acceptable and not an unlawful competition.

Directors must keep information confidential in the performance of their duties. This includes trade secrets and other confidential information received by virtue of their positions. If this duty is violated, the company may bring an action for breach of trust against the wrongdoer, based on unlawful competition or infringement of privacy. However, directors are allowed to use their general fund of skills and knowledge acquired in their positions as directors.

The Companies Act has codified and modified the traditional director's common law duty to avoid conflict of interest. It has codified the self-dealing and fair-dealing rules. The Companies Act provides how the director can perform an operation and acquire a personal financial interest in the transaction, by getting approval from a simple majority resolution of shareholders. If the director, or a related person, has a personal financial interest in the transaction of the company, he or she must make a compulsory disclosure of such an interest. This allows the parties to deal at arm's length in the transaction, as the director does not participate in the meeting that deliberates the contract.

The Companies Act has introduced the notion of joint and several liability between the director and any other person who may be liable for the loss, damages and costs suffered by the company. They include costs of all parties to

\footnotetext{
$135 \mathrm{Ibid}$ s. 77 (10).

136 Ibid s. 77 (7).

${ }^{137}$ Cassim (note 83 above) 65.
} 
the court proceedings and the restoration to the company of any amount it has improperly paid as a consequence of the impugned act. This will alleviate the burden of the company in recovering its damages from responsible persons.

The Companies Act also provides that a court may relieve a director, either wholly or partly, from any liability, on terms the court considers just, if it appears that the director is, or may be, liable but has acted honestly and reasonably; or having regard to all the circumstances of the case, it would be fair to excuse the director. The other significant development is the fact that a director may apply to a court for relief if he or she has reason to apprehend that a claim may be made alleging that he or she is liable. However, the condonation for relief does not cover wilful misconduct or wilful breach of trust.

The Companies Act does not provide a situation for an aggrieved person to bring an action to court to set aside the decision of shareholders or board of directors. It is submitted that this action may be successfully brought if shareholders or the board have committed a fraud on a minority. By codifying the director's duty to avoid conflict of interest, the Companies Act will contribute to the good corporate governance in South Africa.

\section{References}

Books

Cilliers, HS \& ML Benade. Company law $4^{\text {th }}$ ed. (1982)

Gower, LCB et al. Gower's principles of modern company law $4^{\text {th }}$ ed. (1979)

Mongalo, T, C Lumina \& F Kader. Forms of business enterprise theory, structure and operation (2004)

Mongalo, T. Corporate law and corporate governance (2003)

Morse, G \& S Girvin. Charlesworths's company law $7^{\text {th }}$ ed. (2005)

Pettet, B. Company law (2001)

Chapters in books

Blackman, Jooste \& Everingham. Commentary on the Companies Act 2006 vol. 2 at 8-111 to 8-188

Blackman, MS 'Companies' in WA Joubert LAWSA vol. 4 (2) (1996) 209 para 138 - 230 para 137

Journal articles

Achada, T. Don't take what isn't yours (2002) 10 JBL 176 - 179

Beuthin, RC. Corporate opportunities and the non-profit rule (1978) 95 SALJ 458 - 470

Botha, MM "The role and duties of directors in the promotion of corporate governance: a South African perspective" 2009 Obiter $702-715$

Bouwman, N "Avoiding a conflict of interest" 2011 Without Prejudice $28-30$

Cassim, MF "Da Silva v C H Chemicals (Pty) Ltd: fiduciary duties of resigning directors" 2009 SALJ 61 - 70

Cassim, R "Post-resignation duties of directors: the application of the fiduciary duty not to misappropriate corporate opportunities" (2008) 125 SALJ 731.

Christie, M. 'The director's fiduciary duty not to compete' (1992) 55 MLR 506 - 520

Edmunds, E \& Lowry, J "The no conflict - no profit rules and the corporate fiduciary: challenging the orthodoxy of absolutism" 2000 JBL 122 - 142

Grantham, R. Can directors compete with the company? (2003) 16 MLR 109 - 113

Havenga, M. Appropriation of corporate opportunities by directors and employees 2007 TSAR $169-178$

Havenga, M. Competing with the company - when does a director breach his or her fiduciary obligations? (1995) 7 SA Merc LJ 435 - 441

Havenga, M. Corporate opportunities: A South African update (part 1) (1996) 8 SA Merc LJ 40 - 55

Havenga, M. Corporate opportunities: A South African update (Part 2) (1996) 8 SA Merc LJ 233 - 251

Havenga, M. Directors in competition with their companies (2004) 16 SA Merc LJ 275 - 286

Idensohn, K "The meaning of 'prescribed officers' under the Companies Act 71 of 2008" (2012) 129 SALJ 717 - 735

Lowry, J \& Sloszar, J "Judicial pragmatism: directors' duties and post-resignation conflicts of duty" 2008 JBL 83 - 91

Prentice, DD "The corporate opportunity doctrine" 1974 MLR $464-468$

Statutes

Companies Act 71 of 2008

Cases

South Africa

African Claim and Land Co Ltd v WJ Langerman 1905 TS 494

Anderson v Hargreaves 1914 CPD 1027

Atlas Organic Fertilizers (Pty) Ltd v Pikkewyn Ghwano (Pty) Ltd and Others 19812 SA 173 (T)

Cohen v Directors of Rand Collieries Ltd 1906 TS 197

Cybercene Ltd and Others v I- Kiosk Internet and Information (Pty) Ltd 20003 SA 806 (C)

Easyfind International (SA) (Pty) Ltd v Instataplan Holdings and Another 19833 SA 917 (W)

Financial Mail (Pty) Ltd v Sage Holdings Ltd 19932 SA 451 (A)

Harvey Tiling Co (Pty) Ltd v Rodomac (Pty) Ltd and Another 19771 SA 316 (T)

Magnus Diamond Mining Syndicate v Macdonald and Hawthorne 1909 ORC 65 (O)

Movie Camera Company (Pty) Ltd v Van Wyk [2003] 2 All SA 291 (C)

Novick v Comair Holdings Ltd 19792 SA 116 (W)

Osry v Hirsch, Loubser \& Co Ltd 1922 CPD 531

Peffers, NO and Another v Attorneys, Notaries and Conveyancers Fidelity Guarantee Fund Board of Control 19652 SA 53 (C)

Phillips v Fieldstone African (Pty) Ltd and Another 20043 SA 465 (SCA) 
$R v$ Herholdt and Others 19573 SA 236 (A)

Robinson v Randfontein Estate Gold Mining Co Ltd 1921 AD 168

$S v$ De Jager and Another 19652 SA 616 (A)

$S v$ Heller and Another (2) 19641 SA 524 (W)

Sage Holdings Ltd v Financial Mail (Pty) Ltd 19912 SA 117 (W)

Sibex Constructions SA (Pty) Ltd v Injectaseal CC \& Others 19882 SA 54 (T)

Peffers, NO and Another v Attorney, Notaries and Conveyancers Fidelity Guarantee Fund Board of Control 19652 SA 53 (C)

United Kingdom

Aberdeen Rail Co. v Blaikie Brothers 1843 - 60 All ER 249 (HL)

Bamford v Bamford [1969] 1 All ER 696 (CA)

Bell and Another v Lever Brothers Ltd and Others 1932 AC $161(\mathrm{HL})$

Bell v Lever Brothers Ltd 1931 All ER 1 (HL)

Boardman and Another v Phipps [1966] 3 All ER 721 (HL)

Boulting and Another v Association of Cinematograph Television and Allied Technicians [1963] 1 All ER 716 (CA)

Bray v Dord 1895-99 All ER 1009 (HL)

Cavendish - Bentinch v Fenn (1887) AC 652 (HL)

CMS Dolphin Ltd v Simonet \& Another [2001] 2 BCLC 704 (ChD)

Cook v Deeks 1916 AC 554 (HL)

Cowan de Groot Properties Ltd v Eagle Trust PIc 19924 All ER 700 (ChD)

Dranez Ansalt \& Others v Hayet \& Others [2002] 2 BCLC 692 (ChD)

EMB Co Ltd v Dominion Bank 19373 All ER 555 (PC)

Erlanger v new Sombrero Phosphate Co [1874-88] All ER 271

Flamlington Group PIc and Another v Anderson and others [1995] 1 BCLR 474 (ChD)

Guiness Plc v Saunders 19901 All ER 652 (HL)

Hely - Hutchinson v Brayhead Ltd [1967] 2 All ER 14 (QBD)

Imperial Mercantile Credit Association v Coleman (1871) 6 Ch App 555

Industrial Development Consultants Ltd v Cooley 19722 All ER 162 (Assizes)

London and Mashonaland Exploitation Co v New Mashonaland Exploitation Co 1891 WN 165 (ChD)

Nepture (Vehicle Washing Equipment) Ltd v Fitzgerald [1995] 3 All ER 811 (ChD)

Phipps v Boardman and Others 19642 All ER 187 (ChD)

Regal (Hastings) Ltd v Gulliver and Others [1942] 1 All ER $378(\mathrm{HL})$

Tito and Others $v$ Wadell and Others (No 2) [1977] 3 All ER 129 (ChD)

Australia

Beach Petroleum NL v Abbot Tout Russel Kennedy [1999] 33 ACSR 1 (NSW)

Bennetts v Board of Fire Commissioners of NSW (1967) 87 WN (pt 1) (NSW)

Breen v Williams (1996) 186 CLR 71 (HC of A)

Consul Development Pty Ltd v DPC Estates Pty Ltd 1974132 CLR 373 (HC of A)

Furs Ltd v Tomkies (1936) 54 CLR 583 (HC of A)

Harness v Commonwealth Bank of Australia Ltd (1993) 12 ACSR 165 SC (NSW)

Hurley v BGH Nominee (Pty) Ltd (1984) 10 ACLR 197 SC (NSW)

Natural Extracts (Pty) Ltd v Stotter (1997) 24 ACSR 110 (Fed. Court Australia)

Woolworths Ltd v Kelly (1991) 4 ACSR 431 CA (NSW)

Worman International Ltd v Dowyer (1994-1995) CLR 544 (HC of A)

Canada

Canadian Aero Services Ltd v O' Malley (1974) 40 DLR 3d 371 (SCC)

Gray v New Augarita Porcupine Mines Ltd (1952) 3 DLR 1 (PC)

United States of America

Irving Trust Co v Deutch 73 F 2d 121 (2nd $C i r ~ 1934)$ 